\title{
Balkanologie
}

Balkanologie Revue d'études pluridisciplinaires

Vol. III, n² | 1999

Volume III Numéro 2

\section{The last Stop on the Orient Express : The Balkans and the Politics of British In(ter)vention}

\section{Vesna Goldsworthy}

\section{(2) OpenEdition}

\section{Journals}

Édition électronique

URL : http://journals.openedition.org/balkanologie/749

DOI : 10.4000/balkanologie.749

ISSN : 1965-0582

Éditeur

Association française d'études sur les Balkans (Afebalk)

Édition imprimée

Date de publication : 1 décembre 1999

ISSN : 1279-7952

\section{Référence électronique}

Vesna Goldsworthy, «The last Stop on the Orient Express : The Balkans and the Politics of British In(ter)vention », Balkanologie [En ligne], Vol. III, n² | 1999, mis en ligne le 22 juin 2010, consulté le 17 décembre 2020. URL : http://journals.openedition.org/balkanologie/749 ; DOI : https://doi.org/ 10.4000/balkanologie.749

Ce document a été généré automatiquement le 17 décembre 2020.

(c) Tous droits réservés 


\title{
The last Stop on the Orient Express : The Balkans and the Politics of British In(ter)vention
}

\author{
Vesna Goldsworthy
}

1 Although this examination of possible definitions of the Balkans concentrates initially on the human rights discourse which accompanied Western involvement in the former Yugoslavia over the past decade - especially as it preceded and underpinned NATO military action over Kosovo - its aim is not to dissect the rights and wrongs of intervention. Rather, I focus on the way in which the rhetorical strategies used to justify it reflect on the debate about definitions of South-Eastern Europe. Of particular interest in this context is the stance adopted by the British Labour Government, whereby the intervention in the Balkans was described not as a one-off, but as a starting point for a new kind of world-wide humanitarianism. The media's emphasis on a new "ethical" foreign policy was undiminished until the end of 1999, when the renewed Russian military action in Chechenya presented a situation in which the use of Western force, whatever the human rights position, was clearly not considered an option. Humanitarian interventionism or - as Noam Chomsky defined it - "new military humanism"1, practised in the Balkans in the aftermath of the Cold War, proved to be of limited value in relation to Moscow.

\section{Humanitarian intervention?}

2 In his study Feeling Global, Bruce Robbins defines the discourse of human rights as universalising and therefore opposed to the notions of culture determined by differentiation which, he maintains, now dominate academic scholarship ${ }^{2}$. In this context, in the academic circles at least, the human rights debate could prove liberating in its potential ability to transcend the ever increasing production of real and imaginary Others which now marks the culturalist discourse. In practice, however, there are some troubling parallels between the "evangelical" humanitarianism of the 
late 1990s and the enlightened forms of $19^{\text {th }}$-century imperialism. In his article entitled "Globocop? Time to Watch the Watchers ", published in The Nation in 1994 and cited in Feeling Global, C. Douglas Lummiswrites :

We can be confident that only the borders of middling and small countries will show a new legal permeability. These are the same countries whose borders were always permeable throughout the age of colonialism and European continental imperialism : the countries of the Third World and Eastern Europe. However much good might be achieved by, say, Norwegian or Nigerian peacekeepers protecting human rights in Los Angeles or Detroit, it's not something we are likely soon to see ${ }^{3}$.

However different the new humanitarian context might seem when compared to even the most enlightened colonial aspirations, the division between the states which determine the need for an intervention and have the means of conducting it, and the states subjected to new human rights interventionism, remains relatively familiar. One might compare the way in which Paddy Ashdown was considered for the position of Commissioner for Kosovo with the role of his $19^{\text {th }}$ century predecessor as British Liberal Party leader, Gladstone, as the Commissioner for the Ionian Islands. The former French health minister Bernard Kouchner, who was eventually appointed to the Kosovo post in preference to Ashdown, is described as the « inventor of the concept of humanitarian intervention " in his official curriculum vitæ ${ }^{4}$. He is acutely aware of the possibility of being seen in an imperialist role in the Balkans and remains keen to avoid this: "we are not in southern Sudan. We don't have to teach people here how to vote $»^{5}$. However, as in Bosnia-Herzegovina, restrictions imposed on the local media and political organisations have already attracted accusations of a colonialist mentality.

Many political commentators continue to examine both the positive and the negative aspects of "human rights imperialism" in South-Eastern Europe. The time has come, it seems, for the "white man to take up his burden" again. That he - and in very few cases, she - is taking up his burden in the Balkans this time round is perhaps not surprising. In an area populated by white peoples - a part of Europe (even if frequently described by the British Prime Minister Tony Blair as being on the "European doorstep") - this new form of imperialism should in theory be free from any imputations of racism. In Europe, yet obviously different from it, the Balkans provide a suitable context for an exercise in apparently benevolent Western paternalism. The fact that a relatively enlightened and prosperous Balkan federation, such as was once Yugoslavia, has in the course of that exercise become a collection of small to middling states, several of which will remain for the foreseeable future in dire need of foreign caretakers, is most usually ascribed to its "Balkanness" rather than any form of external intervention. The troublesome and bloody nature of Balkan nationalism has offered Britain - as it assumed the leading role amongst the European participants in the military action against the Milošević regime - a timely opportunity for developing a self-promoting and self-congratulatory stance at a time of deep anxiety about its own position in Europe.

5 I am troubled by the possibility that the "new humanitarianism" in the Balkans largely appears to depend on the West's self-attributed status of superior enlightenment, which seems to me very similar to the position of the $19^{\text {th }}$ century enlightened imperialism. "Media-driven" government policy in Britain does open up an opportunity for a more ethical approach to foreign policy. Nonetheless, it also contains a danger that the Western media, and in particular television, with its self-confidence based on its economic strength and its demand to be allowed freedom of movement and absolute 
protection anywhere in the world, puts those whose foreign policy it guides in a position equivalent to that of the $19^{\text {th }}$-century "monarch of all I survey" 6 . Like the explorers, adventurers and map makers who preceded the colonial armies in Africa and Asia, journalists and cameramen announce the arrival of the new "humanitarian" troops. The imperial eye is now watching through the lens of the camera.

\section{Europe vs. Non-Europe}

6 As far as the possible definitions of the Balkans are concerned, the attitudes of the 1990s towards the peninsula seem to leave intact the old hierarchical structures in Europe, whereby the north-west represents the most enlightened corner and therefore occupies the self-conferred leadership role, while the south-east plays out European fears and taboos on the continent's edge. Much as in late-Victorian gothic novels, the Balkans continue to offer a site for the irrational and the obscene, European and yet yielding up nightmares "unthinkable" in Europe. In practical terms, the only way to join Europe is to escape from the Balkans.

7 Instead of a bi-partite, Manichean division into Eastern and Western Europe which dominated the Cold War period, our continent is now divided into "Europe" (i.e. the European Union), "Central Europe" (those at the top of the waiting list to join the European Union), and those "beyond the pale" (i.e. much of the Balkans, Russia, Ukraine, etc.). This division is symbolic and deeply hierarchical, and it has considerable practical consequences on every aspect of cooperation between the West and former "Eastern Europe", from the definition of financial aid ("economic" for Central Europe, "humanitarian" for the Balkans), to visa regimes. The recent introduction of visas for Croatian visitors to Britain was described in the Croatian press as a hostile attempt to push Croatia back into the Balkans. One image that comes to mind is the location for one of the last rounds of Kosovo peace talks in June 1999, an inn by the side of a Macedonian road near Kumanovo, with Yugoslav and Nato army delegations, in combat uniforms, disappearing through the door above which the name, in the Cyrillic alphabet, spells out "Europe 93, owner I. Sadiku". Mr Sadiku probably named his locale after an international football cup or some such event, little knowing that its image would one day be offered five Warholian minutes of fame by the world news media. The symbolism was not lost on Western commentators whose references to Balkan "aspirations" to European status barely attempted to hide condescension. It was ridiculed as a typically "Balkan" image, with the cunning and barbarous little countries trying to gain quick entry by the back door into "our" Europe of peace and plenty.

8 A lot has already been said and written about the different ways in which the Balkans confirm, or undermine, the binary oppositions between the Occident and the Orient, particularly in the context of the orientalist theories developed by Edward Said and his successors over the past two decades. While the post-colonial debate struggled to undo the Orient, many of its projections came to be redirected towards the Balkans (coinciding with the post-1989 reappearance of the area from under the withdrawing tide of Communism). Allegedly European, the Balkans became again a useful repository for feelings of European superiority which could no longer be acted out elsewhere. Instead of contrasting Europe with Africa and Asia and risking accusations of racism, we now often define it as orderly, prosperous and enlightened in comparison with the Balkans. Trying to catch up with a Europe which is itself progressing, the Balkans 
always seem to remain at the same distance away from it - always at the point of "beginning to be civilised", always about to join Europe, always in its backyard, or at best on its doorstep.

9 How should the Balkan peoples react to this type of rhetoric? So long as the hierarchical distinctions are accepted, their reaction as neo-colonial subjects can either be acquiescence and complicity, or a kind of counter-attack. Examples of both these strategies can easily be identified. A deferential attitude can be detected among those Balkan politicians who - like mission-educated Africans or Anglo-Indians in the $19^{\text {th }}$ century - accept the idea of the inferiority of the society which envelopes them, while denying that they are part of it. "Yes, indeed, the Balkans are every bit as Balkan as you say, but we here are really European. If you want the real Balkans, just look at the Barbarians next door ». The media (both Western and "Balkan") frequently tend to amplify this pattern by using the Balkan name very selectively, and rarely in any kind of positive context. Meanwhile, anything positive that comes from the Balkans is attributed to Central Europe. The Macedonian National Ballet, performing at the Riverside Theatre in Hammersmith, London, last year, was described in the programme as "one of the leading Central European ballet companies». A Polish speaker at the Central European Festival held in London in the summer of 1998, talked about Central Europe as the area of Europe which has the largest number of Nobel Prize winners per square kilometre and then referred as his examples to writers such as the Bulgarianborn Elias Canetti, and two novelists from the former Yugoslavia, Ivo Andrić and Danilo Kiš. (Although not a Nobel winner, Kiš was presumably included on the grounds that he most certainly deserved the prize.) Conversely, an unpleasant Central European "exception", Hitler, has been blamed upon the proximity of Vienna to the Balkans ${ }^{7}$.

Central Europe now seems to act as a kind of clearing house for those about to be admitted to the fully-fledged Western status. In the chapter entitled « Where is Central Europe Now », in his new book History of the Present, Timothy Garton Ash writes about the way in which the notion of Central Europe, used until not long ago as a cannon to fire against Russia, is now largely directed against the Balkans ${ }^{8}$. For politicians everywhere, and especially for Polish, Hungarian and Czech politicians - Garton Ash writes - the Manichean contrast between "Central Europe", bathed in light, and "the Balkans" drenched in blood, was irresistible. Central Europeans are seen as "civilised, democratic, cooperative", and therefore have a better chance of joining the EU.

11 Complicity in accepting an opposition between Europe and the Balkans, frequently involves - for Balkan countries - a desperate attempt to escape what is perceived as the bloody grip of the peninsula. In an incisive article entitled "Flight from the Balkans", the Romanian Foreign Ministry official Elena Zamfirescu describes the way in which « the obstinate perpetuation of old prejudices about that area's destiny and destination, has become one of the factors which encourage the flightfrom the Balkans ", while at the same time defining Romania as central-Central European". «For both geographical and geopolitical reasons, fully substantiated by the history of this century", Zamfirescu argues, "the author shares the view that Romania and Hungary could be considered "the centre" of Central Europe. Therefore the term Central-Southern Europe, coined by the author covers the Central-European nations situated south of the Danube $»^{10}$. While explaining that the Romanians define their country as one which is "close to" and not simply "bordering on" the Balkans, Zamfirescu sees Romania's desire to be included in the Western sphere as "a natural one" : "Central Europe is also about 
a sense of belonging and about political options. As a country whose institutional, political, cultural and economic life has been, with the exclusion of the Cold War years, an intrinsic past of the Western world, Romania's desire to be included in Western institutions is a natural one $»^{11}$. Demonstrating a similar attempt to distance his country from the Balkans, at a recent conference entitled NATO and Southeastern Europe: Security Issues for the Early $21^{\text {st }}$ Century, the Slovene speaker asserted: "there is a difference between Southeast Europe and the Balkans. Slovenia is a country of Southeast Europe, but not a Balkan state $»^{12}$. In December 1996, coinciding with the moment when hundreds of thousands of demonstrators in Belgrade were promising to topple Milošević, a German journalist described Serbia as being in the Western Balkans, a first sign of its possible future move into Central Europe. At the moment, it is obviously, and firmly, back in the East even though it is to the West of Romania. In a similar vein, European Union officials now refer to Croatia, Bosnia-Herzegovina, Macedonia, Albania and (only occasionally) Yugoslavia as the Western Balkan countries ${ }^{13}$. Such taxonomic subterfuges, to borrow a phrase from Elena Zamfirescu, might leave Bulgaria as the only - simultaneously Central and Eastern - Balkan country, unless we accept the suggestion that it belongs to South-Central Europe, thereby embracing the idea of the Balkans emptied of the Balkan states.

\section{Conterassaults}

12 The counterassault against such hierarchies comes in different guises. One is exemplified by those who accept the bipolar opposition, but attempt instead to "talk up the other side". The Balkans are described as the cradle and the enduring guardian of European civilisation, while Western Europeans are willingly joining the ranks of the lotus eaters in the fold of American globalism. The Byzantine and Ottoman Empires have found new apologists both in the Balkans and in the West, talking up the advantages of either the Greek-speaking civic commonwealth or the Ottoman Millet system.

13 While "Europe" (i.e. the EU) is itself ambiguously suspended between an attempt to promote and encourage new nation states in the Balkans and an effort to declare nation-statism a bankrupt project, there is no shortage of proponents of every side of the argument. In Central Europe meanwhile, the nation states which are ethnically the most homogenous (Poland, Hungary, Slovenia, Czech Republic) are also the best off, as Garton Ash points out, in the queue of applicants for membership in the (firmly multicultural) European Union.

14 A different kind of couterassault against hierarchical oppositions between Europe and the Balkans now comes from academia - myself included - with a wariness of the new essentialising traps that such a project might present. Here the Balkans are frequently described as mulitply marginal. Always, seemingly, on the borderlines between externally defined entities - Europe and Asia, East and West, this religion and that religion, the Mediterranean and Continental Europe - the Balkans seem destined to remain in a kind of deconstructionist mise-en-abîme. Jacques Derrida's concept of différance[sic], applied to literature, where any section of the text, however minute, always reveals internal contradictions reflected in the whole, seems to be translated into symbolic geography. There is no part of the Balkans which represents a stable identity, everything is defined through difference. This might be profitable for 
academic investigations, but it is not easy to see it as a springboard for constructing any kind of stability. The problem, it seems to me, is that seeing the Balkans as permanently transitional in itself stigmatises the area. It implies - falsely in my belief that other areas are monolithic and not transitional themselves. (To put it crudely: Is this really a differentiaspecifica of the Balkans ? Couldn't we describe the British isles as a transitional area between America and Europe, or Germany as a transitional area between Western and Central/or Eastern Europe ?) Emphasising some uniquely Balkan marginality, we end up where we started. Wishing to undo the privileging of Europeanness, we might fetishise the concept of "transitionality", which is perilously close to reaffirming the idea of culture as a kind of tectonic bloc. The civilisations however minutely we choose to define them - clash, Huntington style, and the Balkan peninsula remains the earthquake zone.

I have to conclude, however, that I am not sure at the moment just how - short of resorting to neo-romanticist constructions - one might talk about the Balkans beyond the culturalist debate which pitches the Self against the Others, seemingly reinforcing the very identities it sets out to undo. On the other hand, and given the degree of cynicism with which it has been exploited until now, the human rights discourse although potentially liberating - might well continue to be seen as useful in providing a set of politically correct rhetorical devices.

In Európa Köldöken (The Navel of Europe), his tellingly titled collection of essays, the Hungarian writer Gyorgy Konrád writes :

One of my heads is Eastern, the other Western...We live on the Western edges of the East and we are forced always to compare things and appearances. We are born comparatists ... We cannot reject either of our sides, hence the paradox in our attitudes. Our specificity is contained in this. In effect, we are never at home. In our permanent abode we are homesick for god knows where... At home, we always feel a bit uneasy.... ${ }^{14}$

While this almost schizophrenic, pervasive anxiety of belonging is certainly not unique to this corner of Europe, few areas seem express it so persistently. If we are ever to begin to feel at home in the Balkans, we need new kinds of definitions pretty desperately.

\section{NOTES}

1. Chomsky (Noam), The New Military Humanism : Lessons from Kosovo, London : Pluto Press, 1999.

2. Robbins (Bruce), Feeling Global: Internationalism in Distress, New York: New York University Press, 1999, p. 72.

3. Lummis (C. Douglas), "Globocop? Time to Watch the Watchers", The Nation, 26/09/94. Quoted in Robbins (Bruce), op. cit., p. 74.

4. Available on the Internet, on

http://www.info-france-usa.org/news/statmnts/kou_bio.htm (5/1/00)

5. Erlanger (Steven), «After Slow Start, U.N. Asserts Role in Running Kosovo », The New York Time, 11/08/99, p. A4. 
6. Cf. Pratt (Mary Louise), Imperial Eyes. Travel Writing and Transculturation, London / New York : Routledge, 1992, pp. 201-227, for an analysis of the "monarch-of-all-I-survey" genre in Romantic and Victorian writing.

7. Kaplan (Robert D.), Balkan Ghosts. A Journey Through History, New York : St Martin's Press, 1993, p. xxiii. «Nazism, for instance, can claim Balkan origins. Among the flophouses of Vienna, a breeding ground of ethnic resentments close to the southern Slavic world, Hitler learned how to hate so infectiously », Kaplan asserts.

8. Garton (Timothy Ash), History of the Present, London : Allen Lane, 1999. Also in « The Puzzle of Central Europe ", The New York Review of Books, 18/03/99.

9. Zamfirescu (Elena), « The Flight from the Balkans », Südosteuropa, 44 (1), 1995.

10. Ibid, p. 53.

11. Zamfirescu (Elena), " Romania's Role in Post-Cold War Central Europe », Occasional Papers in Romanian Studies, (1), 1995.

12. Conference presentation available on http://www.harvard.edu/kokkalis/NATO/nato33.htm (06/01/00). Perhaps any country which denies its Balkan identity is ipso facto Balkan.

13. Bojčić (Miroslav), « Brisanje podela », Vreme, (467), 18/12/99.

14. Konrád (Gyorgy), Európa Köldöken, quoted from the Serbo-Croat translation : Na pupku Evrope, Belgrade : Vreme knjige, 1995, p. 10.

\section{AUTEUR}

\section{VESNA GOLDSWORTHY}

Vesna Goldsworthy teaches English and drama at Birkbeck College, University of London, and St Lawrence University, New York. She is the author of Inventing Ruritania: The Imperialism of the Imagination (Yale UP, 1998). 